\title{
EFEKTIVITAS ANTIHIPERURISEMIA EKSTRAK ETANOL DAUN SELEDRI (EEDS) PADA TIKUS INDUKSI KALIUM OKSONAT
}

\author{
Yasinta Rakanita ${ }^{1, *}$, Hastuti L ${ }^{1}$, Joni Tandi ${ }^{1}$, Sri Mulyani \\ Program Studi farmasi, STIFA Pelita Mas Palu, Sulawesi Tengah ${ }^{1)}$ \\ Jurusan Farmasi, FMIPA, UNTAD Palu, Sulawesi Tengah ${ }^{2)}$ \\ *Email : cintatjokroadhiguno@gmail.com
}

\begin{abstract}
Celery (Apium graveolens Linn) is a plant that contains phytochemicals like alkaloids, flavonoids, saponins, and tannins. This study aims to prove the effectiveness of the ethanol extract of celery leaf in lowering uric acid levels in white male rats and determine the dose of celery leaf extract which is effective in lowering uric acid levels in male rats. Celery leaf extract prepared by maceration with $96 \%$ of ethanol. The design of the study is a randomized block design. Data were analyzed by using statistical test Analysis of Variance (ANOVA) at a significant level $95 \%$ and were using 30 male rats divided into 6 treatment groups, each treatment consisted of five rats. Animals model hyperuricemia were induced by potassium oxonate $250 \mathrm{mg} / \mathrm{kg}$ except the normal group. Group I (normal) researcher provides a standard, group II (negative) suspension given Na CMC 0,5\%, group III (positive) by the suspension of allopurinol 5,4 $\mathrm{mg} / \mathrm{kg}$, groups $\mathrm{IV}, \mathrm{V}$, and VI were given ethanol extract of celery leaf each with a dose of $50 \mathrm{mg} / \mathrm{kg}, 100 \mathrm{mg} / \mathrm{kg}$, and $200 \mathrm{mg} / \mathrm{kg}$. Based on the test result that further BNJ dose of ethanol extract of celery leaf is effective with $50 \mathrm{mg} / \mathrm{kg}$.
\end{abstract}

Keywords: Hyperuricemia, Celery Leaf Extract, Potassium Oxonate

\begin{abstract}
ABSTRAK
Seledri adalah tanaman yang memiliki kandungan kimia seperti alkaloid, flavonoid, saponin, dan tanin. Penelitian ini bertujuan untuk membuktikan efektivitas ekstrak etanol daun seledri dalam menurunkan kadar asam urat pada tikus putih jantan dan menentukan dosis ekstrak daun seledri yang efektif dalam menurunkan kadar asam urat pada tikus putih jantan. Ekstrak daun seledri dibuat secara maserasi dengan pelarut etanol 96\%. Rancangan penelitian yang digunakan adalah Rancangan Acak Kelompok. Data yang diperoleh dianalisis dengan mengunakan uji statistik Analisis Sidik Ragam pada taraf kepercayaan 95\% yang mengunakan 30 ekor tikus putih jantan dibagi 6 kelompok perlakuan, tiap perlakuan terdiri dari 5 ekor. Model hewan dibuat hiperurisemia menggunakan penginduksi kalium oksonat dengan dosis $250 \mathrm{mg} / \mathrm{kg}$ BB. Kelompok I (normal) diberikan pakan standar, kelompok II (negatif) diberi suspensi $\mathrm{Na}$ CMC 0,5\%, kelompok III (positif) diberi suspensi allopurinol $5,4 \mathrm{mg} / \mathrm{kg} \mathrm{BB}$, kelompok IV, V, dan VI diberi ekstrak etanol daun seledri masing-masing dengan dosis $50 \mathrm{mg} / \mathrm{kg} \mathrm{BB}, 100 \mathrm{mg} / \mathrm{kg} \mathrm{BB}$, dan $200 \mathrm{mg} / \mathrm{kg} \mathrm{BB}$. Berdasarkan uji lanjut BNJ diperoleh hasil bahwa dosis ekstrak etanol daun seledri yang efektif adalah $50 \mathrm{mg} / \mathrm{kg} \mathrm{BB}$.
\end{abstract}

Kata kunci: Hiperurisemia, Ekstrak Daun Seledri, Kalium Oksonat 


\section{PENDAHULUAN}

Gaya hidup modern telah membawa manusia dalam kehidupan yang serba instan, praktis dan cepat. Dilihat dari sudut pandang kesehatan, gaya hidup seperti ini tentu saja menimbulkan dampak yang tidak menguntungkan. Akibat dari semua itu banyak orang yang terserang berbagai macam penyakit salah satunya adalah hiperurisemia. ${ }^{1}$ Berdasarkan data Riset Kesehatan Dasar (Riskesdas) 2013 prevalensi penyakit sendi berdasarkan diagnosis di Indonesia $11,9 \%$ dan berdasarkan diagnosis atau gejala sebesar 24,7\%. Prevalensi berdasarkan diagnosis tertinggi terdapat di Bali (19,3 \%), diikuti Aceh (18,3 \%). Berdasarkan diagnosis atau gejala tertinggi terdapat di Nusa Tenggara Timur $(33,1 \%)$, diikuti Jawa Barat $(32,1 \%)$. Sedangkan Sulawesi Tengah berdasarkan diagnosis $(11,4 \%)$ dan berdasarkan diagnosis atau gejala sebesar $(26,7 \%)$. $^{2}$

Hiperurisemia adalah keadaan dimana terjadi peningkatan kadar asam urat darah di atas normal. Pada manusia, asam urat merupakan produk akhir metabolisme purin. Purin yang menghasilkan asam urat dapat berasal dari tiga sumber, yaitu purin dari makanan, konversi asam nukleat jaringan menjadi nukleotida purin, dan sintesis de novo basa purin. Hiperurisemia bisa terjadi karena peningkatan metabolisme asam urat, penurunan pengeluaran asam urat, dan gabungan antara kedua mekanisme tersebut. ${ }^{3}$

Salah satu tanaman yang dapat digunakan dalam pengobatan tradisional oleh masyarakat adalah daun seledri (Apium graveolens Linn). ${ }^{4}$ Penelitian sebelumnya menyatakan bahwa pada dosis $1 \mathrm{~g} / \mathrm{kgBB}$ Fraksi Etil Asetat Daun Seledri menunjukkan efek penurunan kadar asam urat pada tikus putih jantan yang diinduksi dengan kalium oksonat. ${ }^{5}$ Penelitian lain menyatakan bahwa pada dosis $50 \mathrm{mg} / \mathrm{kgBB}$ Fraksi Air Herba Seledri secara signifikan dapat menurunkan kadar asam urat pada mencit hiperurisemia. ${ }^{6}$

Penelitian ini bertujuan untuk mengetahui efek antihiperurisemia EEDS pada tikus putih jantan (Rattus novergicus) yang diinduksi kalium oksonat dan untuk mengetahui dosis EEDS yang efektif memberikan efek antihiperurisemia.

\section{METODE}

Alat : Ayakan, batang pengaduk, bejana maserasi, blender, cawan porselin, corong gelas, erlenmeyer, gelas kimia, gunting bedah, inkubator, kandang hewan uji, kuvet semi mikro, labu ukur, mikropipet, mortir dan stamper, penangas air, pipet tetes, rak tabung reaksi, rotapavor, sendok tanduk, sentrifugator, spektrofotometer UV-Vis sonde oral, spuit injeksi, spuit oral, tabung darah, tabung reaksi, tabung vacutainer, timbangan kasar dan timbangan analitik.

Bahan : Allopurinol, alumunium foil, amoniak, aquadest, aqua pro injection daun seledri, etanol $95 \%, \mathrm{FeCl}_{3}, \mathrm{HCl}$, hewan uji, kalium oksonat, kertas saring, $\mathrm{NaCl}, \mathrm{Na} \mathrm{CMC}$, pakan pellet, pereaksi dragendroff, reagen kit asam urat, sarung tangan dan serbuk magnesium

\section{Pembuatan Sampel}

Bahan uji yang digunakan adalah daun seledri yang diperoleh dari kota Palu Provinsi Sulawesi Tengah. Pembuatan simplisia meliputi diambil dan dikumpulkan secukupnya kemudian disortasi basah, perajangan, dikeringkan dengan cara diangin-anginkan tanpa terkena sinar matahari langsung dan disortasi kering.

\section{Pembuatan EEDS}

Serbuk simplisia diekstraksi secara maserasi dengan pelarut etanol $96 \%$, lalu disaring, dipekatkan dengan rotavapor dan diupakan di atas penangas air. 


\section{Uji Penapisan Fitokimia}

Uji penapisan fitokimia EEDS meliputi uji alkaloid, flavonoid, saponin, dan tannin.

\section{Pemilihan Hewan Uji}

Hewan uji yang digunakan adalah tikus putih jantan berumur 3-4 bulan, berat badan 150-200 gram.

\section{Pengujian Aktivitas EEDS}

Hewan percobaan dikelompokkan menjadi 6 kelompok. Masing-masing terdiri dari 5 ekor. 6 kelompok percobaan tersebut adalah:

1. Kelompok I: Kontrol normal, diberi pakan standar dan aquadest secara peroral.

2. Kelompok II: Diberikan suspensi $\mathrm{Na}$ $\mathrm{CMC}$ dosis $0,5 \% \mathrm{mg} / \mathrm{kg} \mathrm{BB}$

3. Kelompok III: Diberikan suspensi allopurinol dosis $5,4 \mathrm{mg} / \mathrm{kg} \mathrm{BB}$

4. Kelompok IV: Diberikan suspensi EEDS $50 \mathrm{mg} / \mathrm{kg}$ BB

5. Kelompok V: Diberikan suspensi EEDS $100 \mathrm{mg} / \mathrm{kg} \mathrm{BB}$

6. Kelompok VI: Diberikan suspensi EEDS $200 \mathrm{mg} / \mathrm{kg} \mathrm{BB}$

Mulanya hewan dipuasakan selama 18 jam dan ditimbang bobot badannya. Sebelum diberikan perlakuan, hewan uji dibagi menjadi 6 kelompok perlakuan yaitu kelompok 1 (kontrol normal), kelompok 2 (kontrol negatif), kelompok 3 (kontrol positif), kelompok 4 (ekstrak daun seledri $50 \mathrm{mg} / \mathrm{kg} \mathrm{BB}$ ), kelompok 5 (ekstrak daun seledri 100 $\mathrm{mg} / \mathrm{kg} \mathrm{BB}$ ), dan kelompok 6 (ekstrak daun seledri $200 \mathrm{mg} / \mathrm{kg} \quad \mathrm{BB}$ ). Dilakukan pengukuran kadar asam urat awal pada semua kelompok hewan uji. Kemudian diinduksi kalium oksonat secara i.p (interaperitonial) setelah jam ke-2 diukur kadar asam urat setelah induksi, dan diukur kembali kadar asam urat tikus pada jam ke 4 dan ke 6 setelah pemberian larutan uji. Data hasil penurunan kadar asam urat tikus dianalisis dengan uji Analisis Sidik Ragam (ANSIRA) dengan taraf kepercayaan 95\%. Kemudian dilanjutkan dengan uji analisis lanjut BNJ

\section{HASIL PENELITIAN}

Tabel 1. Hasil Uji Fitokimia EEDS

\begin{tabular}{lc}
\hline \multicolumn{1}{c}{ Jenis Uji } & Ket \\
\hline Alkaloid & + \\
Flavonoid & + \\
Saponin & + \\
Tanin & + \\
\hline Ket $:$ Positif $(+)$ & $=$ terdeteksi adanya \\
golongan senyawa yang diuji
\end{tabular}

Tabel 2. Rerata Penurunan Kadar Asam Urat Tikus Jam Ke-4 dan Jam Ke-6

\begin{tabular}{llc}
\hline \multirow{2}{*}{ Kelompok Perlakuan } & \multicolumn{2}{c}{ Kadar Asam Urat (mg/dL) \pm SD } \\
\cline { 2 - 3 } & \multicolumn{1}{c}{ Jam Ke-4 } & Jam Ke-6 \\
\hline Kontrol normal & $2,41 \pm 0,00^{\mathrm{b}}$ & $2,46 \pm 0,00^{\mathrm{b}}$ \\
Kontrol negatif & $3,41 \pm 0,57^{\mathrm{a}}$ & $3,40 \pm 0,30^{\mathrm{a}}$ \\
Kontrol positif & $1,83 \pm 2,23^{\mathrm{b}}$ & $1,13 \pm 2,92^{\mathrm{b}}$ \\
Dosis 50 mg/kgBB & $2,15 \pm 2,24^{\mathrm{b}}$ & $1,74 \pm 2,93^{\mathrm{b}}$ \\
Dosis $100 \mathrm{mg} / \mathrm{kgBB}$ & $2,55 \pm 2,16^{\mathrm{b}}$ & $1,79 \pm 2,30^{\mathrm{b}}$ \\
Dosis $200 \mathrm{mg} / \mathrm{kgBB}$ & $2,00 \pm 2,24^{\mathrm{b}}$ & $2,30 \pm 2,19^{\mathrm{b}}$
\end{tabular}

Keterangan : Abjad yang sama menunjukkan tidak ada perbedaan yang signifikan. Abjad yang berbeda menunjukkan perbedaan yang signifikan. 


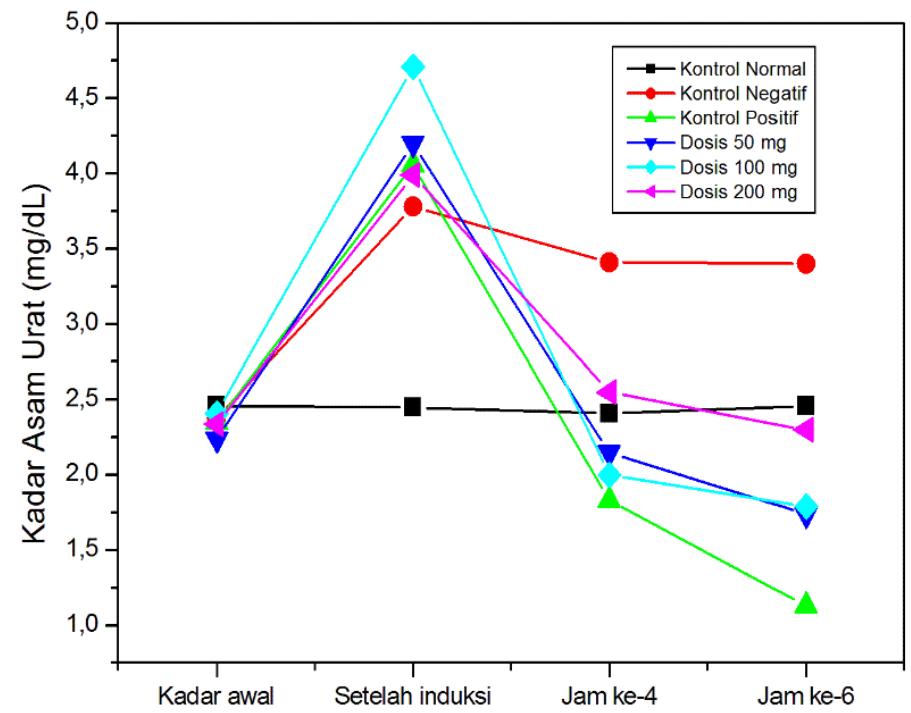

Gambar 1. penurunan kadar asam urat darah tikus putih jantan sebelum perlakuan, setelah induksi dan selama perlakuan.

\section{PEMBAHASAN}

Penelitian ini dilakukan untuk mengetahui aktivitas antihiperurisemia ekstrak etanol daun seledri pada tikus putih jantan yang diinduksi kalium oksonat. Bahan uji yang digunakan adalah daun seledri (EEDS). Metode ekstraksi yang digunakan dalam penelitian ini yaitu metode maserasi. Cairan penyari yang digunakan dalam proses maserasi ini adalah etanol $96 \%$.

Ekstraksi dengan metode maserasi dilakukan perendaman selama $3 \times 24$ jam dengan sesekali diaduk. Hal ini bertujuan untuk menghasilkan penarikan senyawa yang lebih sempurna, sehingga semua senyawa dapat terekstraksi seluruhnya. Pemekatan ekstrak dilakukan pada alat rotavapor dan diuapkan di atas penangas air sehingga diperoleh ekstrak kental daun seledri yaitu 19 gram.

Pengujian fitokimia dilakukan sebagai uji awal untuk mengetahui keberadaan senyawa-senyawa bioaktif yang memberikan khasiat atau efek biologis yaitu senyawa metabolit sekunder yang diharapkan dapat berperan sebagai antihiperurisemia. Pengujian pada ekstrak daun seledri menunjukkan hasil positif terhadap alkaloid, flavonoid, saponin, dan tannin.

Hewan yang digunakan dalam penelitian ini yaitu tikus putih karena tikus memiliki proses absorbsi sistem pencernaan dan sistem metabolisme terhadap obat uji yang relatif mirip dengan sistem pencernaan manusia. Pemilihan tikus putih jantan (Rattus norvegicus) sebagai hewan uji karena tikus jantan memiliki kestabilan hormonal dibanding tikus betina, karena tikus betina mengalami siklus estrus masa kehamilan dan menyusui yang akan mempengaruhi kondisi psikologis hewan uji. Tikus putih Jantan (Rattus norvegicus) tidak memiliki hormon estrogen, walaupun ada jumlahnya sangat sedikit. Hormon estrogen bermanfaat untuk meningkatkan pengeluaran asam urat melalui urin. ${ }^{7}$

Kalium oksonat merupakan inhibitor urikase yang kompetitif untuk menaikkan kadar asam urat dengan cara mencegah asam urat berubah menjadi allantoin dan tidak tereliminasi lewat urin. Kondisi hiperurisemia dibuat dengan menginduksi masing-masing tikus putih 
(Rattus norvegicus) menggunakan kalium oksonat dengan dosis $250 \mathrm{mg} / \mathrm{kg} \mathrm{BB}$ secara intraperitonial. ${ }^{8}$

Allopurinol digunakan sebagai pembanding untuk mengetahui penurunan kadar asam urat bahan uji. Pada umumnya allopurinol dikonsumsi untuk penderita hiperurisemia walaupun waktu paruhnya pendek, allopurinol mengalami biotransformasi dari hexantin oksidase menjadi aloksantin yang waktu paruhnya lebih panjang. Allopurinol merupakan obat urikostatik yang bekerja dengan menghambat xantin oksidase sehingga hipoxantin tidak akan diubah menjadi xantin dan asam urat turun. Adanya penghambatan xantin oksidase meningkatkan hipoxantin dan xantin yang akan banyak diekskresikan lewat urin.

Penetapan kadar asam urat berdasarkan reaksinya enzimatik menggunakan reagen uric acid FS TBHBA (asam 2,4,6 tribromo 3 hidroksi benzoate). Dalam penetapan kadar asam urat yang perlu diperhatikan adalah senyawa penganggu terutama dari sel-sel darah merah yang diketahui yang paling menganggu adalah glutation dan ergotation. Untuk mengatasinya maka diambil serum darah merah dan darah yang diambil diusahakan tidak terjadi hemolisis.

Hasil uji perlakuan pada jam ke-4 antara kelompok kontrol negatif dengan kelompok perlakuan lainnya menunjukkan pada kontrol negatif tikus masih mengalami hiperurisemia yang ditunjukkan dengan kadar asam urat yang tinggi $3,41 \pm 0,57 \mathrm{mg} / \mathrm{dL}$. Hal ini menunjukkan bahwa allopurinol, EEDS $50 \mathrm{mg} / \mathrm{kg} \mathrm{BB}, 100 \mathrm{mg} / \mathrm{kg} \mathrm{BB}$ dan 200 $\mathrm{mg} / \mathrm{kg}$ BB dapat menurunkan kadar asam urat pada tikus jantan yang dibuat hiperurisemia. Kadar asam urat setelah perlakuan yang diperoleh berada pada jam ke-4 adalah 1,83-2,55 mg/dL.

Hasil uji perlakuan pada jam ke-6 antara kelompok kontrol negatif dengan kelompok perlakuan lainnya menunjukkan pada kontrol negatif tikus masih mengalami hiperurisemia yang ditunjukkan dengan kadar asam urat yang tinggi $3,40 \pm 0,30 \mathrm{mg} / \mathrm{dL}$. Hal ini menunjukkan bahwa allopurinol, EEDS $50 \mathrm{mg} / \mathrm{kg} \mathrm{BB}, 100 \mathrm{mg} / \mathrm{kg} \mathrm{BB}$ dan 200 $\mathrm{mg} / \mathrm{kg} \mathrm{BB}$ dapat menurunkan kadar asam urat pada tikus jantan yang dibuat hiperurisemia. Kadar asam urat setelah perlakuan yang diperoleh berada pada rjam ke-6 adalah $(1,13-2,30 \mathrm{mg} / \mathrm{dL})$.

Berdasarkan hasil uji lanjut $\mathrm{BNJ}$ pada jam ke-4 menunjukkan bahwa kelompok dosis EEDS $50 \mathrm{mg} / \mathrm{kg}$ BB memberikan efek yang berbeda tidak signifikan dengan kontrol positif allopurinol dan dengan kelompok dosis EEDS pada pembanding $100 \mathrm{mg} / \mathrm{kg}$ BB dan $200 \mathrm{mg} / \mathrm{kg}$ BB. Hal ini menunjukkan bahwa semua kelompok dosis EEDS memiliki efek dalam menurunkan kadar asam urat tikus putih jantan. Hasil ini ditunjukkan dengan melihat semua kelompok dosis EEDS dan kontrol positif yang diberikan allopurinol terdapat pada wilayah yang sama.

Berdasarkan hasil uji lanjut BNJ pada jam ke-6 menunjukkan hasil yang sama dengan uji BNJ jam ke-6 bahwa secara umum yang menunjukkan ketiga variasi dosis ekstrak etanol daun seledri yaitu $50 \mathrm{mg} / \mathrm{kg} \mathrm{BB}, 100 \mathrm{mg} / \mathrm{kg} \mathrm{BB}$, dan $200 \mathrm{mg} / \mathrm{kg} \mathrm{BB}$ berada dalam satu wilayah dengan kontrol positif, artinya memiliki efek yang sebanding dengan kontrol positif sehingga dapat disimpulkan bahwa ekstrak etanol daun seledri memiliki efek dalam menurunkan kadar asam urat pada tikus putih jantan hiperurisemia.

Senyawa golongan flavonoid bekerja dengan cara menghambat xanthine oksidase sehingga dapat mengurangi poduksi asam urat yang berlebihan, alkaloid juga mampu menekan dan mengurangi frekuensi serangan akut dan menghilangkan rasa nyeri dengan cara menghambat sintesis dan pelepasan leukotrien. Sedangkan senyawa tannin diketahui dapat mengikat radikal bebas selama perubahan purin menjadi asam urat dan tanin juga besifat astrigensi sehingga 
dapat menciutkan selaput lendir. Saponin bekerja dengan cara mengurangi aktivitas enzim xantin oksidase dalam serum. ${ }^{9}$ Pengobatan penyakit gout dapat dilakukan dengan cara menurunkan konsentrasi asam urat dalam darah ataupun dengan mengurangi rasa nyeri yang ditimbulkan. ${ }^{10}$

Dosis ekstrak etanol daun seledri yang paling efektif dalam menurunkan kadar asam urat yaitu dosis $50 \mathrm{mg} / \mathrm{kg} \mathrm{BB}$ yang merupakan variasi dosis ekstrak etanol daun seledri yang terkecil. Hal ini disebabkan karena belum dilakukan uji toksisitas pada dosis 100 dan $200 \mathrm{mg} / \mathrm{kg}$, sehingga penggunaan dosis terkecil dapat meminimalisir efek samping toksik dari ekstrak yang diberikan, artinya dosis 50 $\mathrm{mg} / \mathrm{kg}$ BB merupakan konsentrasi terbaik untuk menurunkan kadar asam urat.

\section{KESIMPULAN}

Berdasarkan hasil penelitian yang telah dilakukan maka dapat disimpulkan bahwa:

1. Ekstrak etanol daun seledri (Apium graveolens Linn.) dengan variasi dosis $50 \mathrm{mg} / \mathrm{kg} \mathrm{BB}, 100 \mathrm{mg} / \mathrm{kg} \mathrm{BB}$ dan $200 \mathrm{mg} / \mathrm{kg}$ BB dapat memberikan efek penurunan kadar asam urat pada tikus putih jantan (Rattus norvegicus).

2 Ekstrak etanol daun seledri (Apium graveolens Linn.) dengan dosis 50 $\mathrm{mg} / \mathrm{kg}$ BB merupakan dosis efektif dalam menurunkan kadar asam urat darah pada tikus putih jantan (Rattus norvegicus).

\section{DAFTAR PUSTAKA}

1. Noviyanti. 2015. Hidup Sehat Tanpa Asam Urat. PT. Suka Buku.Yogyakarta. Hal. 9

2. Riset Kesehatan Dasar. 2013. Laporan Hasil Riset Kesehatan Dasar Indonesia. Departemen Kesehatan RI. Hal: 94-95
3. Tim editor. 2006. Ilmu Penyakit Dalam. Jilid II Edisi IV. Departemen Ilmu Penyakit Dalam Fakultas Kedokteran Universitas Indonesia. Jakarta. Hal 1213.

4. Badan Pengawas Obat dan Makanan RI. 2008. Seledri Sebagai Bahan Obat Alam. Editorial Natural Kos. Vol. 3. Hal 8-9.

5. Ervina, T. 2012. Pengaruh Pemberian Fraksi Etil Asetat Daun Seledri (Apium graveolens Linn.) Terhadap Kadar Asam Urat Serum Darah Tikus Putih Jantan Galur Wistar Hiperurisemia. Skripsi. Hal.110

6. Juwita. dkk, 2014. Pengaruh Fraksi Air Herba Seledri (Apium gravolens L.) Terhadap Kadar Asam Urat Mencit Jantan Hiperurisemia. Prosiding Seminar Nasional dan Workshop "Perkembangan Terkini Sains Farmasi dan Klinik IV" Hal. 187 dan 190

7. Pribadi, A.G. 2008. Penggunaan Mencit dan Tikus Sebagai Hewan Model Penelitian Nikotin. Skripsi Program Studi Teknologi Produksi Ternak Fakultas Peternakan Institute Pertanian. Bogor. Hal 31

8. Sigma Aldrich. 2001. Certificate of Analysis Potassium Oxonate. USA. Hal 45Mun'im Abdul dan Hanani Endang., 2011. Fitoterapi Dasar. Dian Rakyat. Jakarta Hal 285-286

9. Candrawati. 2010. Efek Pemberian Ekstrak Daun Seledri (Apium graveolens Linn.) Terhadap Penurunan Kadar Asam Urat Tikus Putih Jantan (Rattus norvegicus). Fakultas Farmasi Universitas Katolik Widya Mandala. Surabaya. Hal. 50

10. Syarif, A., dkk. 2009. Farmakologi dan Terapi. Edisi 5. Departemen Farmakologi dan Terapeutik Fakultas Kedokteran. Universitas Indonesia. Jakarta. Hal 564 